\title{
TRANSPORTATION COSTS AND THE SOCIAL SAVINGS OF RAILROADS IN LATIN AMERICA. THE CASE OF PERU*
}

LUIS FELIPE ZEGARRA

CENTRUM Católica, The Business School of Pontificia, Universidad Católica del Perú, Perú a

\begin{abstract}
This article estimates the social savings of the railroads in Peru in the late $19^{\text {th }}$ and early $20^{\text {th }}$ centuries. The construction of railroads made it possible for Peruvians to substitute the traditional system of mules and llamas, although only for a few routes. Using primary and secondary sources, I estimate the social savings for 1890, 1904, 1914 and 1918. Social savings ranged between 0.3 per cent and 1.3 per cent of GDP in 1890, but then increased to a range between 3.6 per cent and 9.4 per cent of GDP in 1918. The social savings of railroads in Peru were comparable to those for the United States and Great Britain but were much lower than those for Mexico, Brazil and Argentina, largely because Peru had very few railroads.
\end{abstract}

Keywords: Railroads, transportation, economic development, Peru, Latin America

JEL Classification: N70, N76, R40

* Received 14 June 2012. Accepted 31 October 2012. The author thanks the participants in the Seminar of the Asociación Peruana de Historia Económica in March of 2012 (Lima, Peru) and the V Coloquio del Grupo Cuatrinacional de Estudios Empresariales e Historia Económica in October of 2012 (Bogota, Colombia), for their support, ideas and criticism. He also thanks the comments and suggestions of the anonymous referees who read this article. Finally, he recognises the contribution of the staff of the National Library of Peru, the National Archives of Peru, and the Library of the Pontificia Universidad Católica del Perú, who helped him during the process of data collection.

a Calle Daniel Alomía Robles 125-129, Los Álamos de Monterrico, Santiago de Surco, Lima 33 , Peru. Email: llzegarrab@pucp.edu.pe. 


\section{RESUMEN}

Este artículo estima el ahorro social de los ferrocarriles en el Perú a finales del siglo XIX y principios del siglo XX. La construcción de ferrocarriles hizo posible que los peruanos sustituyeran el sistema tradicional de mulas y llamas, aunque solo para algunas rutas. Usando fuentes primarias y secundarias, estimamos el ahorro social para 1890, 1904, 1914 y 1918. El ahorro social se encontró entre $0.3 \%$ y $1.3 \%$ del PBI en 1890 , pero luego aumentó a un rango entre 3.6\% y 9.4\% del PBI en 1918. El ahorro social de los ferrocarriles en el Perú fue comparable con el de los Estados Unidos y Gran Bretaña, pero mucho menor que en México, Brasil y Argentina, en gran medida porque el Perú tenía muy pocos ferrocarriles.

Palabras clave: Ferrocarriles, Transporte, Desarrollo económico, Perú, América Latina

\section{INTRODUCTION}

For several decades, economists and historians have paid special attention to the social savings of railroads ${ }^{1}$. Railroads yielded social savings because they provided lower cost and faster transportation than the best alternative. Shippers and passengers saved on transport costs and therefore experienced an increase in their surplus by using railroad services. In a seminal article, Fogel (1964) indicated that railroads led to a reduction in transportation costs in the United States in the $19^{\text {th }}$ century, but the savings in transport costs (social savings of the railroad) were relatively low ${ }^{2}$. Railroads did not have a large impact on transportation costs because there

1 In theory, the social savings of the railroad (or its direct effects) measure the increase in social surplus due to the lower transport costs of the railroad with respect to the best alternative. The indirect effects refer to the backward and forward linkages of the railroad with other productive sectors. Our focus in this article will be on the direct effects of the railroad. As indicated by Gunderson (1970), the social saving or direct effects of the railroad measures its social value by comparing two economies: one economy which uses railroads (the actual economy), and another, which is the same actual economy except that it does not have railroads (a hypothetical alternative economy). Empirical research has been conducted by Fogel (1962, 1964, 1979), Fishlow (1964), O'Brien (1983), Hawke (1970), Fremdling (1977), Coatsworth (1979) and Summerhill (2005), among many others. Some might question the relevance of the social savings approach in the sense that railroads were perhaps not an isolated system but rather formed part of a new system. Railroads probably facilitated coordination of other modes of merchandise and passenger transportation. Edgerton (2006), for example, shows the persistence and even increases in the use of animals in England up to the 1930s. Yet, the social saving approach still yields a rough estimate of the increase in social surplus due to the railroad.

2 According to Fogel (1964), the social saving of the railroad in 1890 was 8.9 per cent of GDP. Also for the United States, Fishlow (1964) reports a social saving of 3.7 per cent of GDP in 1859. 
was a system of navigable rivers and canals, which tended to provide fast and low-cost transportation for long distances ${ }^{3}$. Other studies extended the analysis to other countries ${ }^{4}$. In general, it seems that social savings were low in countries where waterways were available. In most of Europe, a system of rivers, canals and coastal routes was also available and, consequently, the social saving of the railroad was usually as low as in the United States. In England and Wales, for example, prior to the railroad, freight was carried by a system of canals and only occasionally by the most expensive system of non-rail land transport ${ }^{5}$.

On the other hand, the evidence indicates that the social savings of the railroad in some Latin American countries was large due to the lack of waterways. For Mexico, Coatsworth (1979) indicates that the social saving of the railroad was larger than in industrialised economies due to the lack of navigable rivers and canals ${ }^{6}$. Most transportation in Mexico was then conducted by wagons and mules. «Except for local freight across three large lakes near highland population centers and short hauls up several rivers from the Gulf to the base of the mountains, internal water transport was unknown" (Coatsworth 1979, p. 947). Also, considering that most Mexicans lived far from the two coasts, coastal shipping did not play the same role as it did in the United States and in Europe. In these circumstances, the construction of railroads led to a large reduction in transportation costs. Similarly, in Brazil, the social savings of Brazilian railroads were large ${ }^{7}$. As indicated by Summerhill (2005), prior to the railroad, freight had to travel over Brazil's coastal mountain range on the backs of mules, or at best on wagons or carts. This system of transportation was costly, so the construction of railroads had a large impact on transportation costs.

3 According to Fogel (1979), «The crux of the transportation revolution of the nineteenth century was the substitution of low-cost water and railroad transportation for high-cost wagon transportation. This substitution was made possible by a dense network of waterways and railroads.... Railroads were indispensable, however, in regions where waterways were not a feasible alternative» (p. 50).

4 Some have calculated the social saving of the railroad for European countries. O'Brien (1983) summarises the main results for Western Europe. For Great Britain, Hawke (1970) estimates the social saving as 4.1 per cent of GDP in 1865 and 11 per cent in 1890. For Russia, Metzer (1974) finds a social saving of 4.6 per cent in 1907. For France, Caron (1983) indicates that the social saving was 5.8 per cent of GDP in 1872. For Germany, according to Fremdling (1983), the social saving was 5 per cent in the 1890s. In the case of Spain, Gómez-Mendoza (1983) indicates that the social saving was 11.8 per cent in 1878 and 18.5 per cent in 1912. For Belgium, Laffut (1983) estimates the social saving as 2.5 per cent in 1865 and 4.5 per cent in 1912 .

5 Hawke (1970) indicates that «for the general merchandise and mineral flows considered here [i.e. the type of output that railroads transported], canal transport is dominant since the flows are mainly inland, and for such cargoes land transport was so expensive as to be considered only when speed was vital» (Hawke, 1970, p. 79).

6 Coatsworth (1979) indicates that the social saving of the railroad in Mexico in 1910 ranged from 24.6 per cent to 38.5 per cent of GDP.

7 Summerhill (2005) indicates that the social saving of the railroad ranged between 18 per cent and 38 per cent of GDP in 1913. 
The aim of this article is to estimate the social savings of the railroad in Peru for the period 1890-1918. Our estimates indicate that the social savings of the railroad ranged between 0.3 per cent and 1.3 per cent of GDP in 1890, but then increased to a range between 3.6 per cent and 9.4 per cent of GDP in 1918. These social savings were similar to those in the United States and other industrialised economies, but were much lower than in Mexico, Brazil and Argentina.

The Peruvian case is interesting because it challenges our view on the factors that influenced the social savings of the railroad. From the studies for the United States, Western Europe and Latin America one might conclude that the social savings of the railroad were large if waterways were not available. The lack of waterways implied that transportation was conducted by the expensive system of overland transportation in wagons or on the backs of animals and men. When looking at the case of Peru, however, one finds that the lack of canals and navigable rivers was not a sufficient condition for large social savings. Peru lacked waterways, but the social savings of railroads were not very high. In fact they were similar to those in the United States and other industrialised economies $^{8}$, and were much lower than in Mexico, Brazil and Argentina.

Railroads were built in Peru from 1850. At that time, the construction of railroads was considered promising by Peruvians. Several argued that Peru would be able to take advantage of its great endowments of natural resources (mining resources and land) with the introduction of the railroad. In the 1850s, Ernest Malinowski argued that with reliable rapid transportation, Peruvians «should be able to compete with analogous goods from other countries. And not just in foreign markets, but even in this country, as wheat, coffee, cacao, and so on prove, which for the coastal consumer now come largely from abroad - even when interior growers can supply them in sufficient quantity, even superior quality» ${ }^{9}$. Later in 1860, Manuel Pardo indicated that the construction of railroads would reduce transportation costs dramatically, allowing the exploitation of natural resources, especially in the central highlands ${ }^{10}$. According to Pardo, «if the locomotive, in other countries, facilitated production and commerce, in ours its mission is much higher: to create what today does not exist; to fertilise and give life to the elements of wealth, which today lie in an embryonic, latent state» ${ }^{11}$.

${ }^{8}$ Social savings for Peru might have even been lower than for the United States and other industrialised economies, considering that the figures for these countries correspond to the $19^{\text {th }}$ century: it is possible that social savings in those economies increased over time.

9 Taken from Gootenberg (1993, p. 91). Malinowski was the engineer in charge of building the Central Railway.

${ }^{10}$ Manuel Pardo was an important businessman and politician, and President of Peru between 1872 and 1876.

11 Gootenberg (1993, p. 80). The support for railroads was not limited to the central region. In Arequipa, for example, several businessmen led by Patricio Gibbons and Joseph Pickering also supported the construction of railroads, because they would foster the «industrial life» of the region. 
In the following decades, several million dollars were invested in rail construction $^{12}$. The total number of kilometres of railway track increased from only 25 in 1855 to 1,792 in $1875^{13}$.

Several historians have questioned the assertion that railroads had a large positive impact on the growth of the Peruvian economy. In his encyclopedic Historia de la República del Perú, Jorge Basadre argued that railroads were not as beneficial as believed in the $19^{\text {th }}$ century, and that Peru required much more than only investing fiscal resources in large rail investment projects. According to Basadre, «it was not enough with spilling the public fortunes to stimulate and develop work, to give to the laborer the conscience of his own strength, to multiply the value of properties and to assimilate the public and private welfare, as it was believed back then" ${ }^{14}$. More recently, Contreras (2004) argued that railroads may have helped to solve transport problems in the central highlands, but the mining sector faced other bottlenecks, such as the lack of disciplined working force and irregularities in provision of inputs (Contreras 2004, p. 172). Moreover, Miller (1976b) argued that the Central Railway only favoured the copper industry ${ }^{15}$. Overall the railway's impact on the economy was much lower than in the copper sector $^{16}$. For instance, little development in arable agriculture took place in the central highlands.

This article complements previous historical studies on Peru by calculating the social saving of the railroad. By calculating the social savings one can determine whether the effects of railroads on transport costs were large or rather small in comparison to the size of the overall economy. The structure of the article is as follows. Section 1 describes the transport system in Peru in the $19^{\text {th }}$ and early $20^{\text {th }}$ century. Section 2 estimates the freight savings, that is the savings in transport costs of shippers due to the railroad. Section 3 estimates the passenger savings, making a distinction between savings on travel fares and time savings. Section 4 compares our results for Peru with those for other Latin American countries. Section 5 concludes the paper.

12 Total rail investment reached as much as 220 million dollars from 1850 to 1900 .

13 In the late 1870s and 1880s, however, the railway network experienced slow growth. By 1904, total track length was 2,042 km. In 1919, Pedro Dávalos and Lisón argued that most mining companies located in Pallasca, Huailas, Cajabamba, Hualgayoc, Cajatambo, Huallanca and some others experienced an «anemic life» because of the lack of means of communication, especially railroads.

14 Basadre (1983, Vol. V, p. 136). On the other hand, Virgilio Roel (1986) did not doubt the potential positive effect of railroads. His criticisms of the actual railroad policies were rather directed against the allocation of railroads, which according to him reoriented the routes of commerce and led to large regional inequalities. The railway system, Roel argued, benefitted the coast while causing major difficulties for the sierra, which remained practically untouched by the steam machine. Roel's criticism of the railway system is in Roel (1986, p. 184, 185).

15 In particular, copper mining and smelting at Cerro de Pasco, Morococha and Casapalca.

16 More recently, Zegarra (2011) indicates that the railroad had forward linkages with the sugar and cotton sectors, and with the copper sector. 


\section{RAILROADS AND ALTERNATIVE MODES OF TRANSPORTATION}

Railroads have operated in Peru since the mid-19 $9^{\text {th }}$ century. The first railroad, which ran between Lima and Callao, started to operate in 1850 . Several railroads were then built in the north, centre and south of Peru, especially during the government of José Balta (1868-1872). In the 1860s and 1870 s there was much optimism surrounding the construction of railroads. There seemed to be almost a consensus that with the construction of railroads Peru could exploit its vast natural resources in mining and agriculture, and foster economic prosperity. The state invested large sums of money, mostly obtained during the guano boom. In 1865-1878, the state invested more than 100 million dollars in building railroads. The railway network then increased from only $87 \mathrm{~km}$ in 1865 to $1,792 \mathrm{~km}$ in 1875 (Figure 1).

The decline in guano reserves and fiscal revenues in the mid-1870s slowed down railroad construction. Moreover, several railroads were destroyed during the War of the Pacific (1879-1883) between Peru and Chile ${ }^{17}$. Railroad length then declined from 2,030 km in 1877 to 1,509 km in 1883 . Furthermore, the war caused a severe economic contraction in Peru and damaged its fiscal finances, making it practically impossible to continue with the construction of railroads for several years.

With the signing of the Grace Contract between the Peruvian state and the Peruvian Corporation in 1889, this foreign corporation took over the administration of state railroads and was committed to investing in reconstructing the damaged lines and expanding the railway track ${ }^{18}$. A British Vice-consul of the time saw the future of Peru with optimism: "The prolongation of the railroads of Peru, consequent on the Bondholders' contract with the government», argued the Vice-consul, "will lead to the opening up of immense agricultural and mining fields, and will give life to all the great national industries of the interior, which so long have been awaiting the means of communication with the coast in order to spring into activity... Peru may reasonably look forward to a prosperous future» ${ }^{19}$. Overall, however, the construction of railroads was a slow process in the 1890s and early 1900s. The railway network increased from $1,509 \mathrm{~km}$ in 1883 to only $1,848 \mathrm{~km}$ in 1903 .

The process of building railroads gathered pace from 1905. The total railroad network increased to almost 3,000 km in 1910 and 3,487 km in 1918 .

17 The following railroads were destroyed during the war: Pacasmayo-La Viña, ChimboteRecuay, Ancon-Chancay, Ilo-Moquegua and the mining railroad of Cerro de Pasco. Also, as Peru was defeated in this war, it lost the province of Tarapaca, including the railroads located in this province, such as the railroads of Pisagua-Sal de Obispo and Iquique-La Noria.

${ }^{18}$ In 1889, the Peruvian state granted the Peruvian Corporation (constituted by the foreign creditors of the state) the administration of state-owned railroads for 66 years in exchange for debt obligations of the Peruvian state.

19 Report of the Trade and Commerce of Callao (Vice-consul Wilson), Parliamentary Papers, 1890, LXXVI, 421, cited in Miller (1976a). 
FIGURE 1

RAILROAD LENGTH (KM).

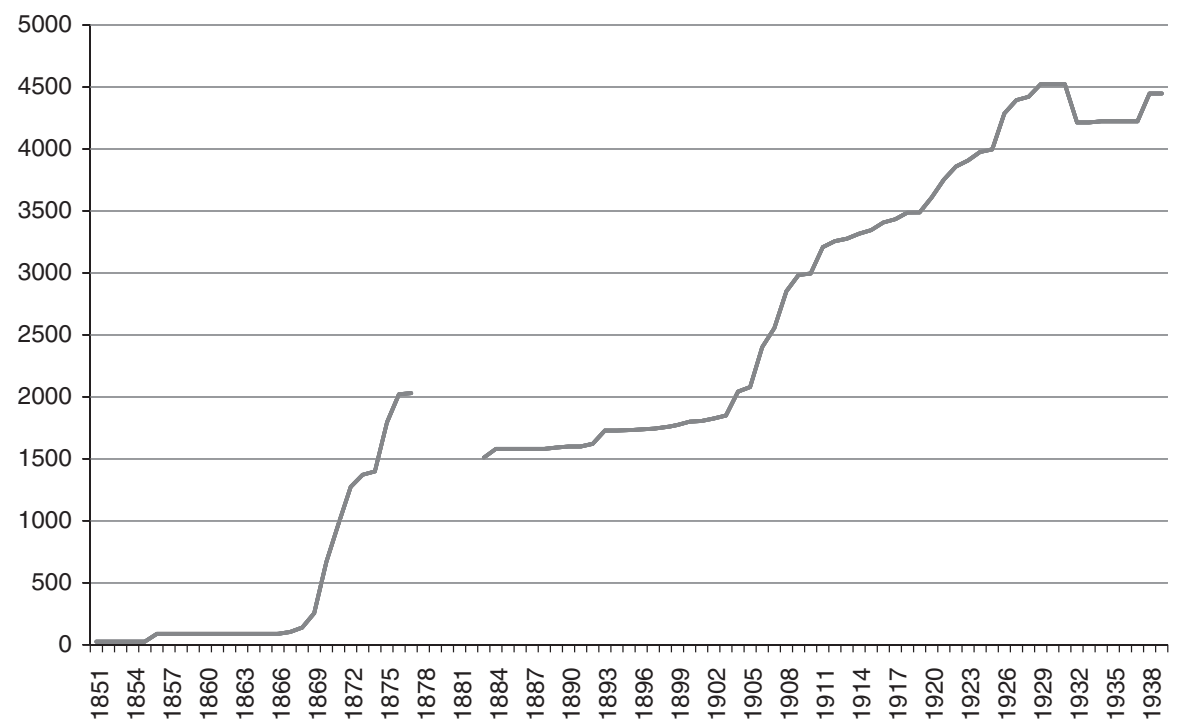

Source: Extracto Estadístico (1939).

However, in terms of railroad density, Peru was far behind many countries in Latin America. By 1913, for example, Peru only had $0.7 \mathrm{~km}$ (around 0.4 miles) of railway track per 1,000 inhabitants, below the Latin American average of $1.4 \mathrm{~km} / 1,000$ inhabitants (Figure 2). Peru was far behind Argentina, which had $4.3 \mathrm{~km} / 1,000$ inhabitants, around seven times more than Peru. Other countries with a clear lead over Peru were Chile, Costa Rica and Uruguay. All of these countries had more than $2 \mathrm{~km} / 1,000$ inhabitants. Other countries with more railway length per-capita than Peru were Mexico, Brazil, Cuba, the Dominican Republic and Panama. In South America, Peru only performed better than Colombia, Ecuador and Venezuela.

The railroad system of Peru of the early $20^{\text {th }}$ century consisted of a long list of railroads, but most of them were very short and were not part of a unified network (Figure 3). Of all the railroads, only two linked the coast and the sierra: the Central Railway and the Southern Railway. The Central Railway connected the port of Callao with the city of Lima and several towns in the central highlands, largely dedicated to mining ${ }^{20}$. The main line of the railway was Callao-Lima-La Oroya. The Peruvian Corporation then built a

${ }^{20}$ This was actually one section of the Central Railway; another section was Lima-Ancon-Chancay. 
FIGURE 2

RAILWAY LENGTH PER 1,000 INHABITANTS (KM).

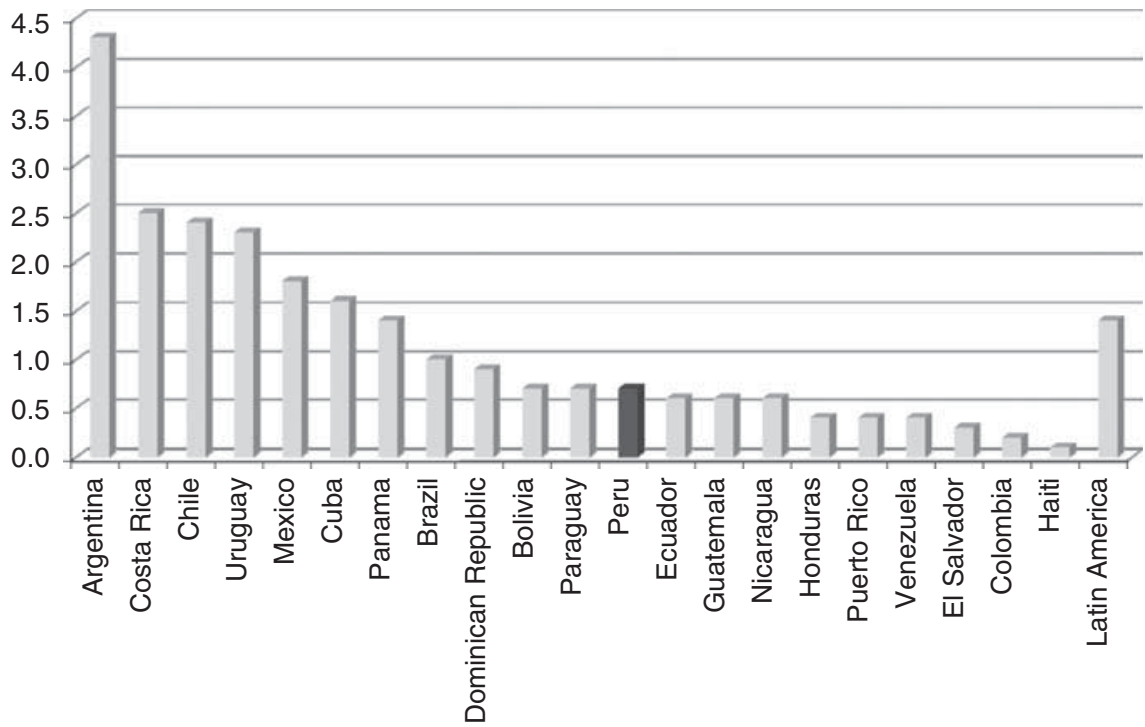

Source: Bulmer-Thomas (2003).

branch from Ticlio to Mororocha in 1900; the Cerro de Pasco Railway Co. built another line from La Oroya to Cerro de Pasco in 1904, extending the area of influence of the Central Railway far beyond La Oroya. The railroad then reached Jauja and Huancayo in 1908. Another railway system, the Southern Railway, connected the coast and the highlands in the south: it linked the port of Mollendo with the departments of Arequipa, Puno and Cuzco. In addition, there were a number of short railroads that connected coastal valleys, the main coastal cities and the Pacific seaboard ${ }^{21}$.

Most Peruvian territory lacked railroad facilities and waterways, and relied on the traditional system of mules and llamas. Dávalos and Lissón (1919) indicates that, according to a study by the engineer Tizón and Bueno, there were around 10,000 towns in Peru in the 1910s and that only 300 of them were connected by railroad in the late 1910s. Similarly, Milstead (1928)

21 Located mostly in the north, these railroads were not part of a unified railway system. Some of the northern railroads were Paita-Piura, Eten-Chiclayo-Patapo, Pacasmayo-Guadalupe and Yonán, and Salaverry-Trujillo-Ascope. In the department of Lima, the steam railroads of LimaCallao, Lima-Chorrillos and Lima-Magdalena operated until the 1900s, when they were replaced by the electrical railroads. Some short railroads were also built on the southern coast; two of them were Pisco-Ica and Tambo de Mora-Chincha Alta. 
FIGURE 3

MAP OF RAILROADS OF PERU, 1850-1930

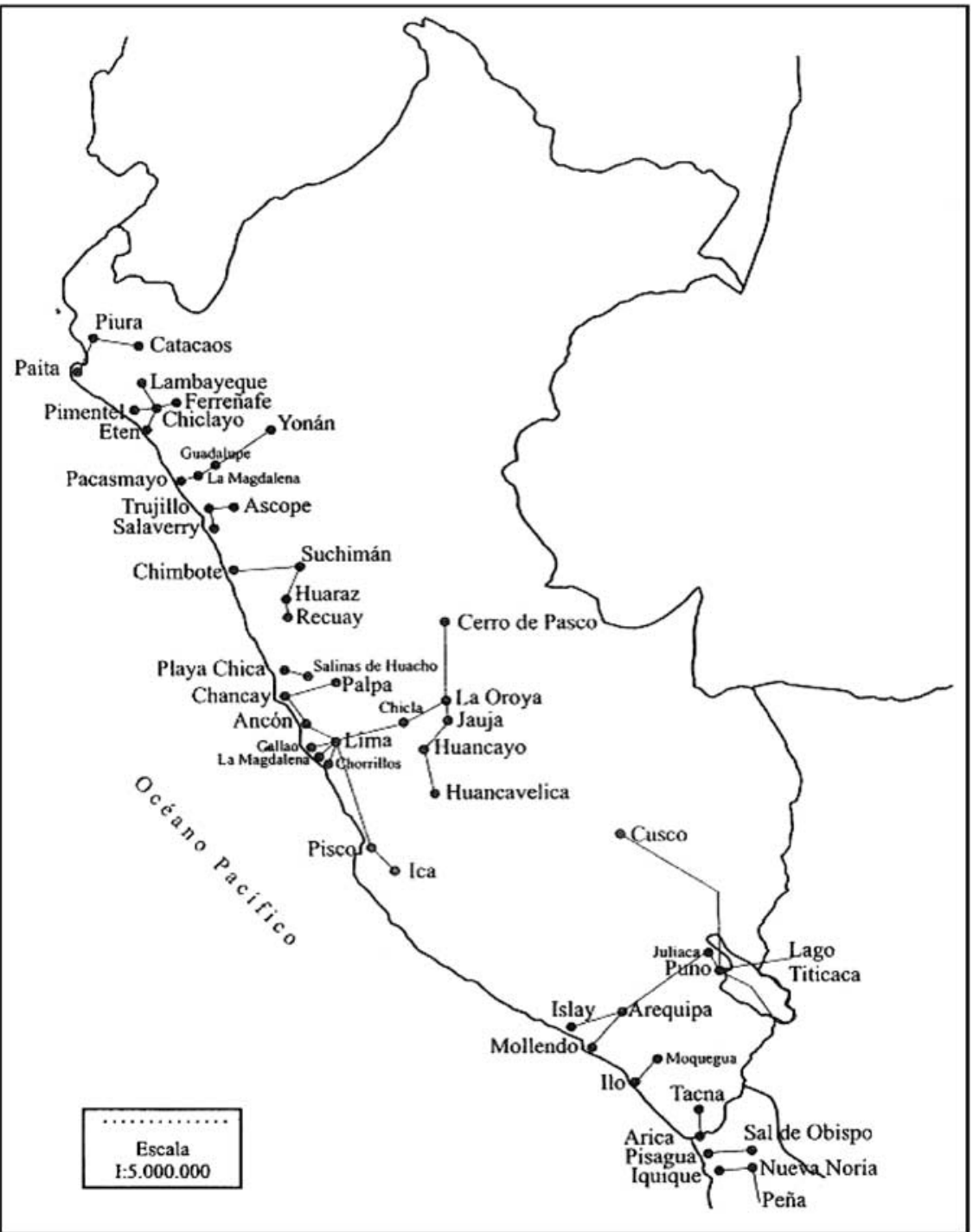

Source: Taken from Deustua (2010), p. 191. 
indicates that railroad infrastructure was very deficient not only in the highlands but also on the coast. According to Milstead, in the early 1920 s primitive transportation facilities persisted in around 85 per cent of the country. Although some railways had been constructed from the 1850 s, there was no integrated railway network: «... most of the railways consist of short isolated lines of varying gauges connecting an ocean port with the chief towns and plantations of the adjacent irrigated valleys» (Milstead 1928, p. 68).

The traditional system of mules and llamas was the closest substitute for railroads in the early $20^{\text {th }}$ century. Several sources indicate that in the absence of railroads in most of the Peruvian territory, mules and llamas were widely used for transportation. The road system in most of the territory was inadequate for wagons. In 1906, Carlos Cisneros indicated that «most transportation was conducted on the backs of mules» (Cisneros 1906, p. 123). In 1921, E. C. Vivian indicated that «the cross-country roads are in general nothing but steep ill-made pack-mule trails» (Vivian 1921, p. 111). In 1927, Clarence Jones indicated that most towns largely depended on the traditional system of mules and llamas (Jones 1927, p. 24). Horses could also be used for transportation along the coast; however, in the extreme conditions of Peru's sandy and dry deserts, mules were probably more suitable than horses ${ }^{22}$. Even on the Lima-Callao route, traffic was «unthinkable without mule trains» (Waszkis 1993, p. 137).

Railroads represented a much faster mode of transportation than mules and llamas. In the central region, for example, a train only took 11 hours to complete the route Lima-Cerro de Pasco, traversing the Andes Mountains. In the south, the Pisco-Ica railroad completed the 48 -mile route in $<4$ hours. In contrast, travellers could take nearly a day by horse through the desert. In addition, freight rates were usually lower for railroads than mules, especially for long routes (Zegarra 2011). Llamas could only compete with railroads in terms of costs: for some routes llamas offered a cheaper system of transportation, which probably explains why a large proportion of bulky products were transported on the backs of llamas even after the construction of railroads ${ }^{23}$.

Mules had some advantages and disadvantages in comparison with llamas. One of the advantages of mules with respect to llamas is that mules

22 The mule was the "camel of the desert»: the endurance of mules under fatigue and indifferent nurture was extraordinary. "... The mule, which more easily supports the difficulties of a severe journey on the sparest food, is, in Peru, the camel of the desert. Without mules a long journey on most parts of the coast would be impracticable. The horse obeys the spur until he falls dead under the rider. Not so the mule: when too weary to journey onward he stands stock still, and neither whip nor spur will move him until he has rested. After that he will willingly proceed on his way. By this means the traveler has a criterion by which he can judge of the powers of his animal...» (Tschudi, 1847, p. 205-206).

23 According to Miller (1976b), around one-third of mining production from Cerro de Pasco was carried to Callao by llamas in 1890 , even though it was possible to transport it by railroad. 
could carry up to 300 pounds, whereas llamas could not carry more than 125 pounds, and even 100 pounds was usually considered a full load (Hills 1860, p. 101). Mules, then, were more appropriate for carrying heavy items. In addition, mules were faster than llamas: mules could complete as much as $60 \mathrm{~km} /$ day, whereas llamas could only cover $\leq 25 \mathrm{~km}$. Finally, mules could stand the heat of the coastal desert; llamas could not. For journeys to or from the coast, then, mules were required at least for part of the route. On the other hand, llamas were more suitable than mules for the difficult terrain and weather of the $\operatorname{Andes}^{24}$, and did not require much care since they were mostly fed from any herbage, which lowered their maintenance costs (Cisneros 1906, p. 124).

Waterways, more efficient than roads, have been widely used wherever they are available. However, in Peru the government never built canals, and rivers were not navigable in the habitable regions. Jones (1927) indicated that the lack of navigable rivers imposed enormous trade handicaps. "No large navigable rivers offer routes into the interior and other means of entering the mountain zone are not easily provided. Between latitudes 5 degrees and 35 degrees south no pass in the Andes lies at an elevation of less than 11,000 feet. The trade handicap because of this situation is enormous» (Jones 1927, p. 151). The Pacific Ocean constituted a faster and cheaper mode of transportation than mules and llamas, especially after the invention of the steam machine. However, its use was naturally constrained to coastal towns. Ocean transportation was as fast and cheap as railroads; however, ocean transportation was not a substitute for railroads: only one railroad ran parallel to the shore ${ }^{25}$.

\section{FREIGHT SAVINGS}

The freight saving of the railroad measures the increase in consumer surplus for freight transportation due to the railroad. Shippers saved in freight transport costs due to the railroad, because railroads charged less than mules and llamas. Two elements have a determinant influence on the size of these freight savings: the difference in freight rates between

${ }^{24}$ Contemporary travellers were aware of these differences between mules and llamas. Hills (1860), for example, indicated that a llama «has spongy hoofs and claws, which enables him to pass over beds of ice with ease, and is well protected by his fleece from any cold to which he may be exposed» (p. 101). Moreover, Cisneros (1906) observed that llamas could live in places where mules would die of hunger and cold. In addition, Tschudi (1847) pointed out that llamas could carry freight from places where the declivities were so «steep that neither asses nor mules can keep their footing» (p. 308).

${ }_{25}$ The railroad Lima-Ancon-Chancay was one branch of the Central Railway. Built in 1869, this was the only railroad that ran parallel to the coast, connecting the city of Lima, the town of Ancon and the valley of Chancay, and passing through several haciendas. During the War of the Pacific, however, the section Ancon-Chancay was destroyed. 
railroads and the best alternative to railroads, and the demand for freight transportation. I calculate the freight savings for 1890-1918. Data on freight services come from Anales de las Obras Públicas (1890-1918) ${ }^{26}$, and information on rail freight rates comes from Miller (1979) and the magazine Economista Peruano ${ }^{27}$.

Considering that most roads were not appropriate for the traction of the wheel, I assume that in the absence of railroads all freight transportation would have been conducted on the backs of mules and llamas. Two alternative scenarios have been considered: the first scenario assumes that only mules could be used instead of railroads, and the second scenario assumes that llamas (cheaper but slower than mules) were used as much as possible in the absence of railroads. The first scenario yields an upper bound for freight savings, and the second scenario yields a lower bound for freight services.

26 The Anales de las Obras Públicas reports information on tonne-km for most railroads. Data are never missing for the Central Railway, the Railroad of Pacasmayo, the Railroad of Trujillo, and the Cerro de Pasco Railway. Data are missing only once for the Southern Railway, for the railroads Paita-Piura, Eten-Chiclayo, Chimbote-Tablones, Tambo de Mora-Chincha Alta, Ilo-Moquegua, and for the electrical railroads. For the railroads of Lima, which operated until 1905, I was not able to find information on the total freight service (in tonne-km) for 1890 and 1904. Using the average freight rate of this railroad from Anales de las Obras Públicas 1890 and Boletin del Ministerio de Fomento 1905, I estimated the volume of tonne-km by dividing the total revenues between the average freight rate. Also, for the year 1890, there are no data on the freight service in tonne-km for the railroads of Paita-Piura, Piura-Catacaos and ChimboteTablones. For Paita-Piura I assumed that the average distance travelled by freight in 1890 was the same as in 1892, for Piura-Catacaos I assumed that the average distance travelled by freight in 1890 was the same as in 1894, and for the railroad Chimbote-Tablones I assumed that the average distance travelled by freight in 1890 was the same as in 1891; I then multiplied the average distance by the total volume of freight (in tonnes) transported by each of those railroads. For 1904, for the Southern Railway and railroads of Piura-Catacaos and Pisco-Ica, there are data for the total volume of freight in tons, but there are no data for the level of freight service in tonne-km. For the Southern Railway, I estimated the distance travelled by freight using interpolation for 1903 and 1905 multiplying such distance by the total tonnage to obtain a figure in tonne-km. For Piura-Catacaos I assumed that the distance travelled by freight in 1904 was the same as in 1905, and for Pisco-Ica I used the average distance travelled by freight in 1903. For 1904, there are no data regarding freight service in tonne-km. For 1914, I estimated the freight service in tonne-km for the railroads of Piura-Catacaos, of Ilo-Moquegua, and the electrical railroads, using the average distance by freight of nearby years. I used the average distance in 1918 for the first two railroads, and the distance in 1913 for the electrical railroads. For 1918, I estimated the freight service of the railroad Tambo de Mora-Chincha using the average distance travelled by freight in 1914.

27 Information on freight rates comes from Miller (1979) and Economista Peruano. Miller (1979) reports average freight rates for the Central Railway, the Southern Railway and the railroad Pacasmayo-Trujillo, which accounted for 86 per cent of total rail freight output (in tonne-km) in 1890 and 87 per cent in 1904. I used Miller's data to estimate the average rail freight rate in 1890 and 1904. The average freight rate is the weighted average of those freight rates, where the weights are the freight output of those railroads in each year. For 1914 and 1918, I used the average freight rate of all railroads from the Peruvian Corporation, which accounted for 55 per cent of freight service in 1914 and 66 per cent in 1918. These rates were reported by the magazine Economista Peruano, Año XI, Vol. IV. No. 125, p. 1418. 
A study for the Peruvian government indicates that renting a mule cost 31.7 cents/tonne-km in 1900 prices $^{28}$. An alternative method for estimating the cost of mule transport provides similar results ${ }^{29}$. For the second scenario, I assume that llamas were used for transportation in the highlands, but not on the coast. Llama freight rates were usually lower than mule rates ${ }^{30}$. Following Tizón and Bueno (1909), I assume that llama rates were half of mule rates. To calculate the cost of transportation in the second scenario, I assume that mules would have carried 30 per cent of freight, and llamas 70 per cent. These percentages reflect the relative importance of highland and coastal freight service, and consider the fact that llamas could not transport freight on the coast ${ }^{31}$.

Let us define $Q$ as the total freight service in tonne-km, $P$ as the freight rate per tonne-km, and $Q=Q(P)$ as the demand function for freight transportation. The freight saving of the railroad $(F S)$ can be calculated as $F S=\int_{P_{R}^{F}}^{P_{F}^{F}} Q(P) d P$, where $P_{R}^{F}$ is the freight rate of railroads, and $P_{N}^{F}$ is the freight

28 The study is Briceño and Salinas (1921). The original figure is in current soles. I deflated that figure by a CPI index reported by Quiroz (1993) to convert the figure into constant soles of 1900.

29 I use a sample of 32 mule freight rates to estimate the effect of distance, railroad competition and economic activity on mule freight rates. With the OLS estimates, I then estimated the mule freight rates if railroads had not existed. The dependent variable is the mule freight rate in soles of 1900/tonne-km denoted as RATE. I measure distance in kilometres, denoting this distance as DIST. I also include a dummy variable to control for the existence of railroads on the same route; this dummy adopts a value of one if there was railroad competition and zero otherwise and is denoted as DUMMY. The regression is $\ln ($ RATE $)=-0.2539 \ln ($ DIST $)-0.7618$ DUMMY +0.0295 . According to the results, an increase of 1 per cent in distance leads to a reduction of 0.25 per cent in the mule freight rate, and railroad competition leads to a decrease of 76 per cent in mule freight rates. I also include three export variables to control for the effect of economic activity: total exports, silver exports and copper exports, but the main results do not change: the estimate for distance remains practically unchanged; whereas the estimated coefficients of the three export variables are not significant. I used the results from the basic regression and the average distance travelled by rail freight to estimate the mule freight rate in the counterfactual economy. The average distance was calculated using information on total freight service (in tonne-km) and total volume of freight (in tonnes) from Anales de las Obras Públicas. The predicted freight mule rates in soles of 1900/tonne-km are 0.38 in 1890, 0.35 in 1904, 0.33 in 1914 and 0.35 in 1918. These results are similar to the rate of 0.31 obtained by Briceño and Salinas (1921). The sources for the mule freight rates are Miller (1976b), Pinto and Salinas (2009), Contreras (2004), Flores-Galindo (1993), Deustua (2009), McEvoy (2004) and Tizón and Bueno (1909), as reported by Zegarra (2011).

30 The lower cost for using llamas is not surprising considering that llamas did not require much care, since they mostly fed upon practically all species of herbage from the mountains, and were better fit than mules for the natural conditions of the Andes. Hills (1860, p. 101). In addition, by the mid- $19^{\text {th }}$ century, the price of a strong fully grown llama ranged between three and four soles, and a regular llama could be purchased for two soles (Tschudi, 1847, p. 308), whereas the price of a regular mule ranged between 45 and 50 soles, and could reach up to 250 soles (Deustua, 2009, p. 176-177).

31 In 1904, around 70 per cent of freight was transported on «highland railroads». To calculate this percentage, I consider as highland railroads the sections of the Central Railway and the Southern Railway located above 1,000 m of altitude. As a percentage of total length, the highland sections represented 77 per cent of the Central Railway and 92 per cent of the Southern Railway (Costa y Laurent, 1908). Assuming that these figures represented the percentages of tonnage carried along the highland sections of the Central and Southern Railways, I find that the highland railroads carried around 70 per cent of total freight service in 1904. 
rate of the second-best alternative to railroad in freight transportation. In the special case in which the demand for freight transportation is perfectly inelastic, the introduction of the railroad does not increase the volume of freight service. Then the saving of the railroad can be calculated as $F S=\left(P_{N}^{F}-P_{R}^{F}\right) Q$.

Table 1 reports the estimation of freight saving for 1890-1918, assuming that the demand for freight transportation was perfectly inelastic, that is, that mules and llamas would have transported the same freight as railroads. Our estimations indicate that freight rail services increased from 19 million tonne-km in 1890 to 208 million in 1918. Railroad revenues then increased from 2.2 million soles in 1890 to 7.8 million soles in 1918. The system of mules and llamas was more costly than railroads for carrying freight. In the first scenario, freight savings increased from only 1.5 per cent of GDP in 1890 to 3.5 per cent in 1904 and 7.5 per cent in $1918^{32}$. In the second scenario, freight savings were 0.68 per cent of GDP in 1890, 1.9 per cent in 1904 and 4.5 per cent in $1918^{33}$.

To understand the changes in freight social savings over this period, let us decompose total freight savings. Denoting $\mathrm{PN}$ as the price of non-rail transport, $\mathrm{PR}$ as the price of railroads, and $\mathrm{QR}$ as the total rail freight service, then freight social savings (FSS) can be decomposed as follows:

$$
\frac{F S S}{G D P}=\frac{(P N-P R)\left(Q_{R}\right)}{G D P}=\left\lfloor\frac{(P R)(Q)}{G D P}\right\rfloor\left[\frac{P N}{P R}-1\right]
$$

The first element in the last expression, $\frac{(P R)(Q)}{G D P}$, measures the size of the railroad sector (as percentage of GDP); and the second element, $\frac{P N}{P R}-1$, measures the relative difference in freight rates between non-rail and rail transportation. The freight social savings are large if the size of the railroad sector is high and/or if the difference in prices between non-rail transport and railroads is large.

Table 2 shows the decomposition of freight social savings. The results indicate that the size of the railroad sector remained below 2 per cent of GDP over this period of time. In fact, although the size of the railroad sector increased from 0.8 per cent of GDP in 1890 to 1.7 per cent in 1914, it then declined to 1 per cent in 1918. The main factor that explains the changes in the FSS is the relative price of non-rail transport with respect to railroads.

32 GDP figures have been calculated using information from Seminario et al. (2010). Seminario et al. (2010) report estimates for the GDP of Peru in constant dollars of 2000 from 1830. I converted the GDP of 1900 from dollars into soles (soles of 1900). To obtain GDP figures for 1890, 1904, 1914 and 1918, I used the growth rate of real GDP (in constant dollars) of those years with respect to 1900. The final GDP figures are in constant soles of 1900.

33 Under the alternative method of estimating mule and llama freight rates, freight savings were not very different. In the first scenario, freight social savings increased from only 1.95 per cent of GDP in 1890 to 3.9 per cent in 1904 and 8.2 per cent in 1918. In the second scenario, freight savings were 0.97 per cent of GDP in 1890, 2.2 per cent in 1904 and 5 per cent in 1918. 
TABLE 1

FREIGHT SOCIAL SAVINGS, 1890-1918

\begin{tabular}{|c|c|c|c|c|c|}
\hline \multicolumn{2}{|c|}{ First scenario } & \multirow{2}{*}{$\begin{array}{l}\mathbf{1 8 9 0} \\
19.29\end{array}$} & \multirow{2}{*}{$\begin{array}{l}1904 \\
62.41\end{array}$} & \multirow{2}{*}{$\frac{1914}{163.41}$} & \multirow{2}{*}{$\begin{array}{c}1918 \\
208.10\end{array}$} \\
\hline (A1) & Freight service (million tonne-km) & & & & \\
\hline (A2) & Rail freight rate (soles per tonne-km) & 0.11 & 0.07 & 0.06 & 0.04 \\
\hline (A3) & Freight rail revenues (line A1 × line A2) (million soles) & 2.18 & 4.32 & 10.38 & 7.75 \\
\hline (A4) & Freight rate by mule (soles per tonne-km) & 0.32 & 0.32 & 0.32 & 0.32 \\
\hline (A5) & Freight revenues by mule (line A $1 \times$ line A4) (million soles) & 6.12 & 19.79 & 51.81 & 65.98 \\
\hline (A6) & Savings on freight rates (line A5-line A3) (million soles) & 3.93 & 15.46 & 41.43 & 58.24 \\
\hline & $(\% \mathrm{GDP})$ & 1.50 & 3.50 & 6.65 & 7.48 \\
\hline \multicolumn{6}{|c|}{ Second scenario } \\
\hline (B1) & Freight service (million tonne-km) & 19.29 & 62.41 & 163.41 & 208.10 \\
\hline (B2) & Rail freight rate (soles per tonne-km) & 0.11 & 0.07 & 0.06 & 0.04 \\
\hline (B3) & Freight rail revenues (line $\mathrm{A} 1 \times$ line $\mathrm{A} 2$ ) (million soles) & 2.18 & 4.32 & 10.38 & 7.75 \\
\hline (B4) & Freight rate by mule and llamas (soles per tonne-km) & 0.21 & 0.21 & 0.21 & 0.21 \\
\hline (B5) & Freight revenues by mule and llama (line B $1 \times$ line B4) (million soles) & 3.98 & 12.86 & 33.68 & 42.89 \\
\hline \multirow[t]{2}{*}{ (B6) } & Savings on freight rates (line B5-line B3) (million soles) & 1.79 & 8.54 & 23.30 & 35.14 \\
\hline & $(\%$ GDP $)$ & 0.68 & 1.93 & 3.74 & 4.51 \\
\hline
\end{tabular}

Notes: Figures in soles are in 1900 prices. The freight social savings have been calculated assuming that the demand for freight transport was perfectly inelastic. 
TABLE 2

DECOMPOSITION OF FREIGHT SOCIAL SAVINGS

\begin{tabular}{|l|c|c|c|c|c|c|}
\hline & \multicolumn{3}{|c|}{ First scenario } & \multicolumn{3}{c|}{ Second scenario } \\
\hline & Social saving (\% GDP) & A & B & Social saving (\% GDP) & A & B \\
\hline 1890 & 1.50 & 0.83 & 1.80 & 0.68 & 0.83 & 0.82 \\
\hline 1904 & 3.50 & 0.98 & 3.58 & 1.93 & 0.98 & 1.97 \\
\hline 1914 & 6.65 & 1.67 & 3.99 & 3.74 & 1.67 & 2.24 \\
\hline 1918 & 7.48 & 0.99 & 7.52 & 4.51 & 0.99 & 4.54 \\
\hline
\end{tabular}

Notes: The computation of the freight social savings assumes that the demand for transportation in perfectly inelastic. The first scenario assumes that only mules would have transported freight in the counterfactual economy. The second scenario assumes that llamas would have been used on the highland routes.

$\mathrm{A}=$ Size of the railroad sector $(\% \mathrm{GDP}) . B=(P N-P R) / P R$.

In the first scenario, the ratio $\frac{P N}{P R}-1$ was 1.8 in 1890 , was above 3.5 in 1904 and 1914, and then increased to almost 8 in 1918. These changes in the relative price of non-rail transportation with respect to railroads is explained by the decline in constant soles of the rail freight rate 0.11 soles/tonne-km in 1890 to 0.07 in 1904 and then to 0.04 in 1918. In contrast, our estimates of mule and llama rates are the same over this period of time ${ }^{34}$.

The assumption that mules and llamas would have transported the same freight as the railroad is questionable. This assumption implies that the demand for freight transportation was perfectly inelastic. However, the demand for freight transportation may be elastic to the freight rate; so in the absence of the railroad, the more expensive system of mules and llamas would probably have carried a lower volume of freight. Facing a higher cost of transportation, the economy would have optimally chosen a lower volume of transportation. Therefore, the assumption of null price elasticity may overestimate the total freight transport cost for using the alternative system of mules and llamas, and may then overestimate the lower bound of the freight consumer savings of the railroad. To calculate the true lower bound of the freight savings, we need to use an upper bound of the price elasticity of the demand for freight transportation.

Table 3 reports the estimates of freight savings for alternative assumptions about the price elasticity of the demand for freight services for 1918, employing the formula $F C S=\int_{P_{R}^{F}}^{P_{N}^{F}} Q(P) d P$ to calculate freight savings. The values of the freight savings in the first scenario range from 17 million soles

\footnotetext{
${ }^{34}$ With the alternative method of estimating mule and freight rates, these rates are also relatively stable over this period of time.
} 
TABLE 3

FREIGHT SAVINGS FOR ALTERNATIVE VALUES OF THE PRICE ELASTICITY OF THE DEMAND FOR FREIGHT SERVICES, 1918

\begin{tabular}{|l|c|c|c|c|}
\hline & \multicolumn{2}{|c|}{ First scenario } & \multicolumn{2}{c|}{ Second scenario } \\
\hline Price elasticity & Million dollars & $\%$ GDP & Million dollars & $\%$ GDP \\
\hline 0 & 58.24 & 7.48 & 35.14 & 4.51 \\
\hline-0.25 & 41.17 & 5.29 & 26.95 & 3.46 \\
\hline-0.5 & 29.72 & 3.82 & 20.96 & 2.69 \\
\hline-0.75 & 21.95 & 2.82 & 16.55 & 2.12 \\
\hline-1 & 16.59 & 2.13 & 13.26 & 1.70 \\
\hline
\end{tabular}

Notes: Figures are in soles of 1900.

TABLE 4

UPPER AND LOWER BOUNDS FOR FREIGHT SOCIAL SAVINGS

\begin{tabular}{|l|c|c|c|c|}
\hline & \multicolumn{2}{|c|}{ Upper bound } & \multicolumn{2}{c|}{ Lower bound } \\
\hline & Million soles & $\%$ GDP & Million soles & $\%$ GDP \\
\hline 1890 & 3.93 & 1.50 & 1.31 & 0.50 \\
\hline 1904 & 15.46 & 3.50 & 4.71 & 1.07 \\
\hline 1914 & 41.43 & 6.65 & 12.22 & 1.96 \\
\hline 1918 & 58.24 & 7.48 & 13.26 & 1.70 \\
\hline
\end{tabular}

Notes: The table reports upper and lower bounds for freight social savings in million soles of 1900 and as percentage of GDP. The upper bound estimates assume that the demand for transportation was perfectly inelastic, whereas the lowest bound considers a price elasticity of -1 .

to 58 million soles. The values of freight savings in the second scenario range from 13 million soles to 35 million soles.

In the following sections, I will use a value of one as an upper bound of the price elasticity of the demand for freight transport ${ }^{35}$. Therefore, I will use a price elasticity of one for the calculation of the lower bound of the freight saving of the railroad. Meanwhile, I will use a price elasticity of zero for the calculation of the upper bound of the freight social saving. Table 4 reports the upper and lower bounds of freight social savings for 1890-1918. Freight social savings ranged between 0.5 per cent and 1.5 per cent of GDP in 1890, increasing then to a range between 1.7 per cent and 7.5 per cent of GDP in 1918.

35 Summerhill (2005) estimates an upper bound of one for the price elasticity; whereas Coatsworth (1979) estimates an upper bound of 0.75 . 


\section{PASSENGER SAVINGS}

The passenger savings of the railroad measure the increase in consumer surplus for passenger transportation due to the railroad. I calculated the passenger savings for 1890-1918, considering savings on travel fares and time savings $^{36}$. Passenger service (in passenger-km) was obtained from Anales de las Obras Públicas for 1890-1918 ${ }^{37}$. In addition, the magazine Economista Peruano reports the average passenger fare of the Peruvian Corporation for 1913-1914 and 1918-1919, without distinction between first- and secondclass passengers. I used these average fares to estimate the total savings on travel fares for 1914 and 1918 , respectively ${ }^{38}$. I also assume that the cost of travelling by mule was 7.6 cents/person $/ \mathrm{km}$ in 1900 prices $^{39}$.

36 There were probably other types of social savings for rail passengers. The comfort of travelling by train, rather than riding a mule or simply walking, yielded benefits to rail passengers. Those comfort-benefits for passengers were not included in the estimation of social savings.

37 For the calculation of passenger social savings, it is important to have information on passenger-km per class. I then assumed that in each railroad the distance travelled by first- and second-class passengers was the same. Data on passenger service in passenger-km have been obtained or estimated from the Anales de las Obras Públicas for several years. Data on passenger service for the Central Railway, the Southern Railway, the Railroad of Pacasmayo, the Railroad of Trujillo, and for the railroads of Pisco-Ica and Supe-Barranca were never missing, whereas data for the railroad of Paita-Piura, Eten-Chiclayo, Chimbote-Tablones, the Cerro de Pasco Railway and the electrical railroads were missing once. Data on passenger service in passenger-km are available for most railroads. In a few cases, I had to estimate the level of passenger service. For the railroads of Lima, I estimated the level of passenger service in 1890 and 1904 using information on the total revenues from passenger transportation, the total number of first-class and second-class passengers and the first-class and second-class fares. For 1890, data on passenger service is missing for the railroads of Paita-Piura, Eten-Chiclayo, and Chimbote-Tablones. Since the Anales reports data on total passengers for those three lines, I estimated the passenger service multiplying the total number of passengers by an estimate of the average distance travelled by passengers. For the railroads of Eten-Chiclayo and Chimbote-Tablones, I assumed that such distance in 1890 was the same as in 1891. For the railroad Paita-Piura, I followed a similar method, but used the average distance of 1893 as a proxy for the distance of 1890 . For 1904, in the cases of the railroads of Tambo de MoraChincha Alta and Pisco-Ica, I had to interpolate the number of passengers using information for 1903 and 1905. The Anales also provides information on passenger-km for most railroads. For the electrical railroads and for the short railroads of Piura-Catacaos, Tambo de Mora-Chincha Alta and Pisco-Ica, there is no information on passenger-km. For the electrical railroads and the railroad Piura-Catacaos, I estimated the number of passenger-km using information on the total revenues from passenger transportation, the total number of first-class and second-class passengers and the first-class and second-class fares. For the railroads of Tambo-Chincha Alta and Pisco-Ica, I used the distance travelled by passengers in those railroads for 1901 and 1903 to estimate the number of passenger-km travelled by those railroads. For 1914, I estimated the level of passenger service for the railroad Piura-Catacaos, Cerro de Pasco Railway, the electrical railroads and the railroad Ilo-Moquegua: for these railroads, I assumed that the average distance of passengers in 1914 was similar to that in 1918. For 1918, I estimated the level of passenger service for Tambo de MoraChincha Alta, assuming that the average distance of passengers in 1918 was similar to that in 1914.

38 Economista Peruano, Año XI, Vol. IV, No. 125, p. 1418

39 In a report for the Peruvian government, Briceño and Salinas (1921) indicates that the cost was 20 current cents (p. 14). Deflated by the CPI index, I obtain 7.6 cents in 1900 prices. Alternatively, I estimated the passenger fare by mule using the results from the regression in footnote 27. Those results provide information on the possible cost of renting a mule/tonne-km. I assume that 
Railroad passengers had alternative modes of transportation at their disposal. The alternative for first-class rail passengers was to travel by mule, since this was the best alternative mode of travel (the other alternative was to walk). For second-class rail passengers, the mode of transportation in the counterfactual economy may have been walking. Travelling by mule was too costly for these passengers. In 1904, for example, an average rail trip covered around $12.6 \mathrm{~km}^{40}$. Such a trip took 3.1 hours on foot and 1.4 hours by mule ${ }^{41}$. Considering the hourly salary, the opportunity cost of walking $12.6 \mathrm{~km}$ (the average journey) was 0.41 soles $^{42}$, whereas the opportunity cost of travelling by mule was 0.19 soles. Walking, however, implied no fare, whereas travelling by mule costs 0.96 soles. In sum, the total cost of travelling on foot was 0.41 soles, whereas the total cost of travelling by mule was 1.14 soles, almost three times as much. Considering these differences in total cost between riding a mule and walking, I assume that second-class rail passengers would have walked in the absence of railroads.

\section{(F'note continued)}

one mule was needed for a person to travel. One mule could carry around $120 \mathrm{~kg}$. Using information on the average distance travelled by rail passengers in 1890, 1904, 1914 and 1918, I estimated the passenger fare in soles of 1900 per passenger-kilometer for each of those years. The estimated fares range between 5 and 6 cents in 1900 prices.

40 I estimated this figure using data from Anales de las Obras Públicas 1904.

41 Briceño and Salinas (1927) reports information about the speed of mules and walking. Briceño and Salinas indicates that mules completed $10 \mathrm{~km} /$ hour on the coast and $6 \mathrm{~km} /$ hour in the highlands (p. 14). In 1904 around 70 per cent of rail passenger service (in passenger-km) corresponded to coastal railroads (including the coastal sections of the railroads Callao-Oroya and the Southern Railway). Then the average speed of mules in kilometers per hour was $10 \times 0.7+6 \times 0.3=8.8$. Briceño and Salinas (1927) indicates that walking took around 15 minutes/ $\mathrm{km}$, at a speed of $4 \mathrm{~km} /$ hour.

42 The estimated salary was 0.17 soles per hour in prices of 1900 . To estimate this salary, I used data on agricultural and non-agricultural salaries. Data from the Extracto Estadístico 1928 indicate that daily agricultural wages in 1915 were 1.24 current soles on sugar farms in 1912, 1.05 current soles on cotton farms, and 0.93 current soles on rice farms. Using those wages from sugar, cotton and rice, and the respective number of workers, daily agricultural wages were 1.109 current soles. This figure was deflated with the CPI Index. Assuming that the workers laboured 10 hours/day, the average hourly wage in prices of 1900 was 7.9 cents for agricultural workers. Non-agricultural wages come from Pino (1910). Pino reports average wages for men and women labourers in eighteen factories in Lima in 1910. On average, men's wages were 2.42 soles/day, and women's wages were 1.55 soles/day. The average daily wage was then 2.125 current soles. Assuming that the labourers worked 10 hours/day, the average hourly wage was 21 cents in current prices or 17.6 cents in prices of 1900 for non-agricultural workers. The figures from Pino (1910) are reported by Torrejón (2010, p. 190). Other sources report similar figures for non-agricultural wages. According to Cisneros (1911), daily wages in 1911 in current prices were 1.4 soles for carpenters, 2.6 for tanners, 2.75 for blacksmiths, 1.2 for labourers (peones), 3.25 for tailors, 3 for upholsterers, 3.5 for typesetters, 2.4 for weavers, 2.75 for shoemakers and 4 for machinists. To calculate the average hourly wage, I used the percentage of population in agriculture and other productive sectors. I used interpolation to estimate the total population, the population younger than 15 years old (assumed not to be part of the labor force) and the rural population for 1904, using data from the census of 1876 and the census of 1940. The portion of the rural population dedicated to agriculture of 1940 was used to approximate the population in agriculture in 1890, 1904, 1914 and 1918. 
I also assume that the same number of rail passengers (in first and second class) would have continued travelling in the counterfactual economy. Savings on travel fares $(P C S F)$ are calculated as follows: $P C S F=\left(P_{N}^{P}-P_{R}^{P}\right) Q$, where $P_{R}^{P}$ is the price of passenger service by railroad, and $P_{N}^{P}$ is the price of passenger services using the alternative mode of transportation.

Table 5 reports the results. Our estimates indicate that first-class rail passenger service increased from 10 million passenger-km in 1890 to 192 million in 1918, and second-class rail passenger service increased from 25 million passenger-km in 1890 to 46 million in 1918. Savings on travel fares were always negative for second-class rail passengers and positive for first-class passengers. In total, savings on travel fares were negative in 1890 but exceeded 12 million soles in 1918 (or 1.6 per cent of GDP) ${ }^{43}$.

To calculate the value of the time saved by rail passengers, we need information on the speed of trains, mules and walking. I assume that passenger trains operated at $23 \mathrm{~km} / \mathrm{hour}^{44}$, mules covered around $8.8 \mathrm{~km} / \mathrm{hour}$, and walking took, on average, 15 minutes $/ \mathrm{km}^{45}$. I assume that passengers participated in the labour force in the same proportion as the general population ${ }^{46}$. I also assume that the value of time was equal to the opportunity cost of time, that is the salaries foregone by travelling instead of working. I assume the following wages for rural and urban workers in prices of 1900: 7.9 cents per hour in agriculture, and 17.6 cents/hour in the rest of the economy ${ }^{47}$. I also assume that second-class passengers earned on average those wages, and that first-class rail passengers earned on average twice as much as those wages.

Table 6 reports the main calculations. The average passenger journey for first-class passengers declined over time, especially after the construction of the electrical railroads in 1904, which were much shorter than other railroads and mostly had first-class passengers. For second-class passengers, however, the average passenger journey remained between 12 and $14 \mathrm{~km}$. Peruvians increased their hour savings over time. The number of hours that

43 These figures have been calculated assuming that the demand for first-class passenger transportation was perfectly inelastic. Assuming that the elasticity was equal to -1 , the fare savings on first-class passenger transport would be 0.09 million soles in 1890 (rather than 0.10 million) and 0.77 million soles in 1904 (rather than 1.35 million). Due to the lack of information on fares/class for 1914 and 1918, it was not possible to calculate the first-class fare savings for these years assuming that elasticity was equal to -1 .

44 This calculation is based on information from Costa y Laurent (1908), which reports journey times for all railroads. I calculated a weighted average of the speeds of trains, where the weights were the level of passenger service of each railroad.

45 See a previous note in this section for more information on the speed of mules and walking.

46 I interpolated the percentages of labour force in total population and of labour force in agricultural in total labour force using data from the censuses of 1876 and 1904, as explained in a previous note in this section.

47 I estimated these salaries in 1900 prices using secondary sources. The sources and methods employed to estimate the agricultural and non-agricultural salaries are indicated in a previous note in this section. 
TABLE 5

SAVINGS ON TRAVEL FARES, 1890-1918

\begin{tabular}{|c|c|c|c|c|c|}
\hline \multicolumn{2}{|c|}{ First-class rail passengers } & \multirow{2}{*}{$\begin{array}{r}1890 \\
9.90\end{array}$} & \multirow{2}{*}{$\begin{array}{r}1904 \\
27.50\end{array}$} & \multirow{2}{*}{$\frac{1914}{148.35}$} & \multirow{2}{*}{$\frac{1918}{191.64}$} \\
\hline (A1) & $\begin{array}{l}\text { First-class passenger service (million } \\
\text { passenger-km) }\end{array}$ & & & & \\
\hline (A2) & $\begin{array}{l}\text { First-class rail rate (soles per passenger- } \\
\mathrm{km} \text { ) }\end{array}$ & 0.066 & 0.027 & & \\
\hline (A3) & $\begin{array}{l}\text { First-class passenger rail revenues } \\
\text { (line } \mathrm{A} 1 \times \text { line } \mathrm{A} 2) \text { (million soles) }\end{array}$ & 0.65 & 0.74 & & \\
\hline (A4) & Passenger revenues by mule (million soles) & 0.75 & 2.09 & 11.29 & 14.58 \\
\hline (A5) & Savings on travel fares (million soles) & 0.10 & 1.35 & & \\
\hline \multicolumn{6}{|c|}{ Second-class rail passengers } \\
\hline (B1) & $\begin{array}{l}\text { Second-class passenger service (million } \\
\text { passenger-km) }\end{array}$ & 24.61 & 46.99 & 39.07 & 46.11 \\
\hline (B2) & $\begin{array}{l}\text { Second-class rail rate (soles per passenger- } \\
\mathrm{km} \text { ) }\end{array}$ & 0.041 & 0.017 & & \\
\hline (B3) & $\begin{array}{l}\text { Second-class passenger rail revenues } \\
\text { (line } \mathrm{B} 1 \times \text { line } \mathrm{B} 2)(\text { million soles) }\end{array}$ & 1.00 & 0.78 & & \\
\hline (B4) & $\begin{array}{l}\text { Passenger revenues by alternative mode of } \\
\text { transport (walking) (million soles) }\end{array}$ & 0.00 & 0.00 & 0.00 & 0.00 \\
\hline (B5) & Savings on travel fares ${ }^{2}$ (million soles) & -1.00 & -0.78 & & \\
\hline \multicolumn{6}{|c|}{ All rail passengers (for 1914 and 1918) } \\
\hline (C1) & $\begin{array}{l}\text { Total passenger service (line A1 + line B1) } \\
\text { (million passenger-km) }\end{array}$ & & & 187.42 & 237.74 \\
\hline$(\mathrm{C} 2)$ & Average rail rate (soles per passenger-km) & & & 0.02 & 0.01 \\
\hline (C3) & $\begin{array}{l}\text { Total passenger rail revenues (line } \mathrm{C} 1 \times \\
\text { line } \mathrm{C} 2 \text { ) (million soles) }\end{array}$ & & & 2.92 & 2.39 \\
\hline \multicolumn{2}{|c|}{ Total savings on travel fares ${ }^{3}$ (million soles) } & -0.90 & 0.57 & 8.37 & 12.20 \\
\hline & $(\%$ GDP) & -0.34 & 0.13 & 1.34 & 1.57 \\
\hline
\end{tabular}

Notes: All figures in soles are in prices of 1900. Passenger revenues by mule in line A4 was calculated as line A1 times the estimated passenger rate by mule.

${ }^{1}$ For 1890 and 1904, savings on travel fares for first-class passengers are equal to line A4 -line A3.

${ }^{2}$ For 1890 and 1904, savings on travel fares for second-class passengers are equal to line B4 line B3.

${ }^{3}$ For 1890 and 1904, total savings on travel fares are equal to line A5 + line B5. For 1914 and 1918, total savings are equal to line A4 + line B4 -line C3. 
TABLE 6

TIME SAVINGS FOR RAIL PASSENGERS

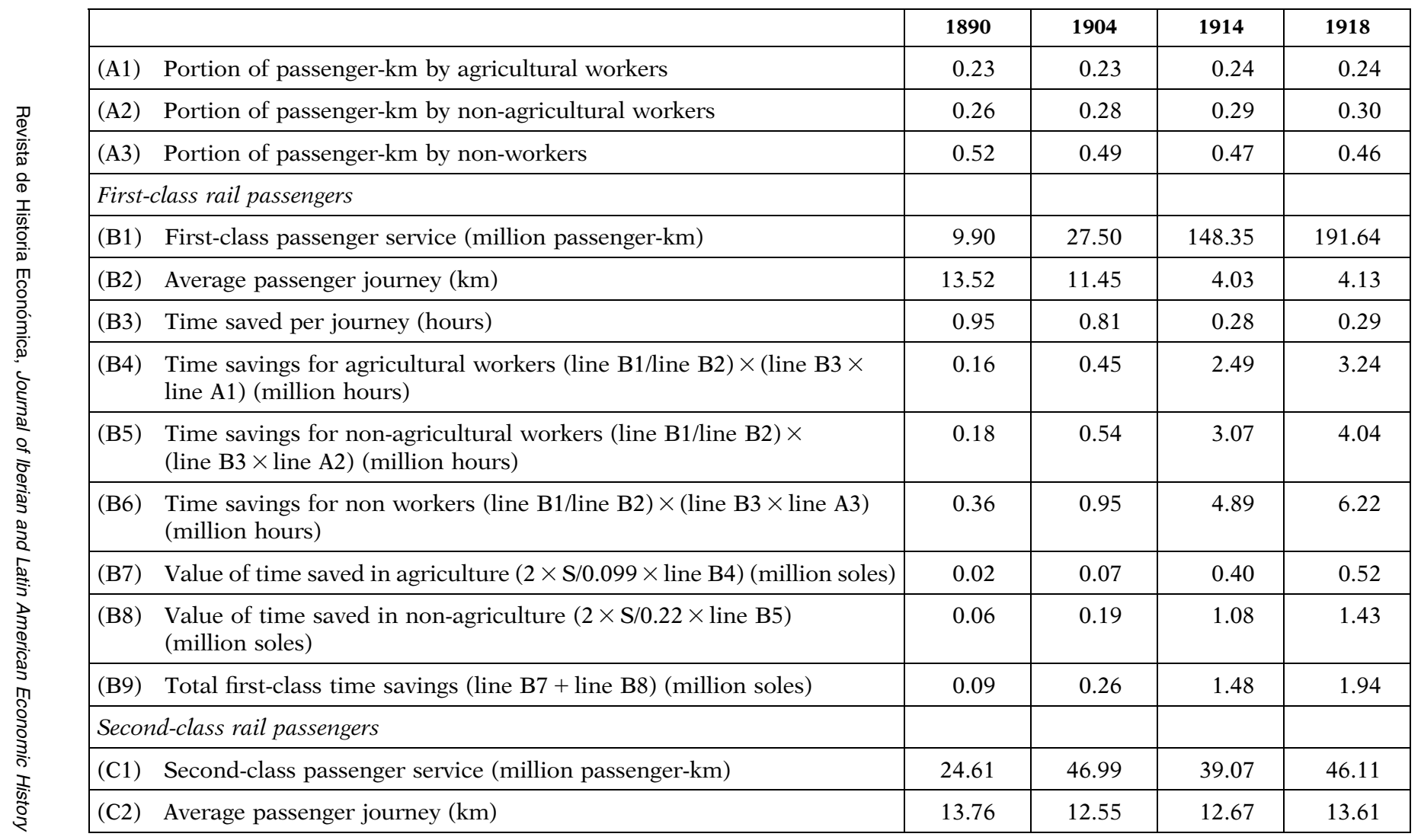


TABLE 6 (Cont.)

\begin{tabular}{|c|c|c|c|c|c|}
\hline (C3) & Time saved per journey (hours) & 2.85 & 2.60 & 2.62 & 2.81 \\
\hline (C4) & $\begin{array}{l}\text { Time savings for agricultural workers (line } \mathrm{C} 1 / \text { line } \mathrm{C} 2) \times(\text { line } \mathrm{C} 3 \times \\
\text { line A1) (million hours) }\end{array}$ & 1.15 & 2.27 & 1.93 & 2.29 \\
\hline$(\mathrm{C} 5)$ & $\begin{array}{l}\text { Time savings for non-agricultural workers (line C1/line C2) } \times \\
\text { (line } \mathrm{C} 3 \times \text { line A2) }(\text { million hours) }\end{array}$ & 1.32 & 2.71 & 2.37 & 2.85 \\
\hline$(\mathrm{C} 6)$ & $\begin{array}{l}\text { Time savings for non-workers (line C1/line } \mathrm{C} 2) \times(\text { line } \mathrm{C} 3 \times \text { line A3) } \\
\text { (million hours) }\end{array}$ & 2.63 & 4.74 & 3.78 & 4.39 \\
\hline$(\mathrm{C} 7)$ & Value of time saved in agriculture $(\mathrm{S} / 0.099 \times$ line $\mathrm{C} 4)($ million soles $)$ & 0.09 & 0.18 & 0.15 & 0.18 \\
\hline$(\mathrm{C} 8)$ & Value of time saved in non-agriculture $(\mathrm{S} / 0.22 \times$ line $\mathrm{C} 5)$ (million soles) & 0.23 & 0.48 & 0.42 & 0.50 \\
\hline (C9) & Total second-class time savings (line C7 + line C8) (million soles) & 0.32 & 0.66 & 0.57 & 0.69 \\
\hline \multicolumn{2}{|r|}{ Total time savings (line B9 + line C9) (million soles) } & 0.41 & 0.92 & 2.05 & 2.63 \\
\hline & $(\% \mathrm{GDP})$ & 0.16 & 0.21 & 0.33 & 0.34 \\
\hline
\end{tabular}

Note: All figures in soles are in prices of 1900. 
Peruvians saved due to the railroads increased from $<6$ million hours in 1890 to 18 million hours in 1914 and 23 million hours in 1918. The value of time savings, however, was not very high: time savings were only 0.16 per cent of GDP in 1890; and although they increased over time, they were only 0.34 per cent of GDP in 1918.

\section{COMPARATIVE ANALYSIS}

The introduction of railroads led to an increase in consumer surplus. The total social saving of the railroad is calculated as the sum of freight savings and passenger savings. Table 7 summarises the social savings of the railroads in 1890-1918, using the estimations from the previous two sections. Social savings ranged between 0.3 per cent of GDP and 1.3 per cent in 1890, increasing to a range between 3.6 per cent and 9.4 per cent in 1918 .

Table 8 compares our results with those for other countries, assuming that the demand for transportation was perfectly inelastic. The main difference in the Latin American sample is related to freight social savings. In all of these countries, passenger savings were usually much lower than freight savings. In fact, passenger savings were usually below 2 per cent of GDP. The only exception was Brazil, where passenger social savings were more than 4 per cent of GDP. There were some important differences in freight savings across countries. Freight social savings were much lower in Uruguay, Colombia and Peru than in Mexico, Brazil and Argentina. Whereas freight

TABLE 7

SOCIAL SAVINGS OF THE RAILROAD (\% GDP)

\begin{tabular}{|c|r|c|c|c|}
\hline & $\mathbf{1 8 9 0}$ & $\mathbf{1 9 0 4}$ & $\mathbf{1 9 1 4}$ & $\mathbf{1 9 1 8}$ \\
\hline Savings on passenger services & & & & \\
\hline (1) Savings on travel fares & -0.34 & 0.13 & 1.34 & 1.57 \\
\hline (2) Time savings & 0.16 & 0.21 & 0.33 & 0.34 \\
\hline (3) Total & -0.19 & 0.34 & 1.67 & 1.90 \\
\hline (4) Savings on freight services & & & & \\
\hline (a) Upper bound & 1.50 & 3.50 & 6.65 & 7.48 \\
\hline (b) Lower bound & 0.50 & 1.07 & 1.96 & 1.70 \\
\hline (5) Total social savings & & & & \\
\hline (a) Upper bound (line 3 + line 4a) & 1.32 & 3.84 & 8.32 & 9.38 \\
(b) Lower bound (line 3 + line 4b) & 0.31 & 1.41 & 3.63 & 3.61 \\
\hline
\end{tabular}

Note: The figures in this table come from Table 4, Table 5 and Table 6. 
TABLE 8

SOCIAL SAVINGS, UPPER BOUND (\% GDP)

\begin{tabular}{|l|c|c|c|c|}
\hline & & Freight savings & Passenger savings & Social savings \\
\hline Mexico & 1910 & 38.50 & 1.38 & 39.88 \\
\hline Brazil & 1913 & 38.37 & 4.03 & 42.40 \\
\hline Argentina & 1913 & 19.90 & 1.72 & 21.62 \\
\hline Uruguay & $1912-1913$ & 3.83 & 1.92 & 5.75 \\
\hline Colombia & 1927 & 7.86 & & 8.32 \\
\hline Peru & 1914 & 6.65 & 1.67 & 9.38 \\
\hline Peru & 1918 & 7.48 & 1.90 & \\
\hline
\end{tabular}

Notes: In all cases, it is assumed that the demand for transportation is perfectly inelastic.

Sources: For Mexico, Coatsworth (1979); for Brazil, Summerhill (2005); for Argentina and Uruguay, Herranz-Loncán (2011); for Colombia, Ramírez (2000); for Peru, see Table 7.

savings were higher than 19 per cent of GDP in Mexico, Brazil and Argentina, the corresponding figure was below 8 per cent in Uruguay, Colombia and Peru.

The decomposition of freight savings into the size of the railroad sector and the relative price factor $\frac{P N}{P R}-1$ may help us understand the differences across countries. Table 9 shows the decomposition of freight savings. In Peru, the size of the railroad sector was always below 2 per cent of GDP, whereas the freight rate of non-rail transportation ranged between 3.2 and 5 times the average rail freight rate in 1914 and between 5.5 and 8.5 times in 1918. Peru had lower freight social savings than Mexico, Brazil and Argentina largely due to the smaller size of the railroad sector (as percentage of GDP). Uruguay and Colombia had similar social savings to Peru, mostly because the size of its railroad sector was, like Peru, very low.

The main explanation for the relatively low level of social savings of Peru is the small size of the railroad sector. In Peru, the size of the railroad sector was below 2 per cent of GDP, whereas it was more than 4 per cent in Mexico, almost 3 per cent in Brazil and 3.6 per cent in Argentina. Even with the reduction in freight rail rates in 1918, the revenues of the Peruvian railroad sector represented a much lower portion of the economy than in Mexico, Brazil and Argentina.

The size of the railroad sector may be explained by the low levels of investment in railroad construction. Railroad length increased in the early $20^{\text {th }}$ century. However, rail density was very low by Latin American standards. In 1913, for example, railroad length per 1,000 inhabitants in Peru was $0.7 \mathrm{~km}$, below the Latin American average of 1.4. In comparison with Mexico, Argentina, Brazil and Uruguay, Peru had a low railway density. 
TABLE 9

DECOMPOSITION OF FREIGHT SOCIAL SAVINGS

\begin{tabular}{|c|c|c|c|c|c|c|c|}
\hline & & & & \multicolumn{2}{|c|}{ Freight rates } & \multirow[b]{2}{*}{$\begin{array}{l}\text { Ratio } \\
(2) /(1)\end{array}$} & \multirow[b]{2}{*}{$\begin{array}{c}\text { Non-rail } \\
\text { transport }\end{array}$} \\
\hline & $\begin{array}{c}\text { Freight social } \\
\text { saving (\% GDP) }\end{array}$ & $\begin{array}{l}\text { Size of railroad } \\
\text { sector ( } \% \text { GDP) }\end{array}$ & $\begin{array}{c}(\mathbf{P N}-\mathbf{P R}) / \\
\text { PR }\end{array}$ & PR (1) & PN (2) & & \\
\hline Mexico (1910) & $24.6-38.5$ & $4.05-5.93$ & $4.1-9.5$ & $0.006-0.009$ & $0.05-0.07$ & $5.1-10.5$ & Wagons \\
\hline Brazil (1913) & $18.7-38.4$ & 2.88 & $6.5-13.3$ & 0.024 & $0.182-0.347$ & $7.5-14.3$ & Wagons \\
\hline Argentina (1913) & 19.9 & 3.62 & 5.50 & 0.008 & 0.049 & 6.50 & Wagons \\
\hline Uruguay (1912-1913) & 3.83 & 1.44 & 2.67 & 0.012 & 0.045 & 3.67 & Wagons \\
\hline Colombia (1927) & 7.86 & 1.12 & 7.00 & 0.022 & 0.176 & 8.00 & Mules \\
\hline & 3.37 & 1.12 & 3.00 & 0.022 & 0.088 & 4.00 & Wagons \\
\hline Peru (1914) & 6.65 & 1.67 & 3.99 & 0.032 & 0.158 & 4.99 & Mules \\
\hline & 3.74 & 1.67 & 2.24 & 0.032 & 0.103 & 3.24 & $\begin{array}{c}\text { Mules and } \\
\text { llamas }\end{array}$ \\
\hline Peru (1918) & 7.48 & 0.99 & 7.52 & 0.019 & 0.158 & 8.52 & Mules \\
\hline & 4.51 & 0.99 & 4.54 & 0.019 & 0.103 & 5.54 & $\begin{array}{c}\text { Mules and } \\
\text { llamas }\end{array}$ \\
\hline
\end{tabular}

Notes: Freight social savings are decomposed into the size of the railroad sector (as \% of GDP) and the factor (PN-PR)/PR, where PN is the non-rail freight rate and PR is the rail freight rate. The size of the railroad sector is calculated as total freight rail revenues as percentage of GDP. Freight rates in (1) and (2) are in constant dollars of 1900. Original data are in pesos of 1900 for Mexico, milreis of 1913 for Brazil, sterling pounds of 1913 for Argentina and Uruguay, current pesos for Colombia and soles of 1900 for Peru. Sources: Coatsworth (1979) for Mexico, Summerhill (2005) for Brazil, Herranz-Loncan (2011) for Argentina and Uruguay, Ramírez (2000) for Colombia, and Table 1, Table 5 and Table 6 for Peru. 
TABLE 10

RATIO SOCIAL SAVINGS/LENGTH OF THE RAILROAD SYSTEM

\begin{tabular}{|l|c|c|c|c|}
\hline & & Freight savings & Passenger savings & Social savings \\
\hline Mexico & 1910 & 1.95 & 0.07 & 2.02 \\
Brazil & 1913 & 1.56 & 0.16 & 1.72 \\
Argentina & 1913 & 0.59 & 0.05 & 0.65 \\
Uruguay & $1912-13$ & 1.49 & 0.75 & 2.23 \\
Colombia & 1927 & 3.29 & & \\
Peru & 1914 & 2.01 & 0.50 & 2.51 \\
Peru & 1918 & 2.14 & 0.55 & 2.69 \\
\hline
\end{tabular}

Notes: The ratio is calculated as the social savings (as \% of GDP) divided by the total length of the railway system. In all cases, it is assumed that the demand for transportation is perfectly inelastic.

Sources: Social savings as percentage of GDP come from Coatsworth (1979) for Mexico, Summerhill (2005) for Brazil, Herranz-Loncán (2011) for Argentina and Uruguay, Ramírez (2000) for Colombia, and Table 7 for Peru. The length of the railroad system comes from Mitchell (1993).

In fact, controlling for the length of railway system, Peru did not have a low social saving. Table 10 reports the ratio social savings (as percentage of GDP) divided by the total length of railroad system (in thousands of kilometres). This ratio was not relatively low for Peru. Compared to Brazil, Uruguay, Argentina and Mexico, Peru actually had a high social saving, once the length of the railroad system has been controlled. Therefore, it seems that a main reason for the low level of social savings of railroads in Peru (as percentage of GDP) was simply the lack of railway track.

Some evidence suggests that railroad companies did not face a high demand for rail transportation, which therefore led to low revenues and a small size of the railroad sector. This problem was certainly more severe in the $19^{\text {th }}$ century. According to Bonilla (2005), for example, the demand for the Central Railway was limited prior to the operations of the Cerro de Pasco Corporation. The Central Railway incurred losses in 1892, and from 1894 to 1899. Similarly, the Southern Railway incurred losses between 1893 and 1899. These problems were less severe in the $20^{\text {th }}$ century, but profitability in the 1900s and 1910s was still low. Miller (1976a), for example, estimates that the rate of return of the Peruvian Corporation was below 2 per cent in the 1890s, remained between 2 per cent and 3 per cent in the 1900s and only exceeded 5 per cent in the 1920s. There were, then, low incentives to invest in this sector.

Most of the demand for rail transportation came from exports. Railroads mostly served the copper export sector of the central highlands, and the sugar and cotton haciendas on the coast, especially in the northern coastal departments. For example, more than 50 per cent of the freight transported 
by the Central Railway in 1923-1924 was silver and copper. In contrast, agricultural products from the Mantaro Valley in the department of Junin represented only a small fraction of the volume of freight transported by the Central Railway. In 1923-1924, agricultural products only represented 5 per cent of the volume of freight and represented 10 per cent of the revenues of the railroad for transporting freight ${ }^{48}$. As Miller (1979) indicates, "The [Central] railway, against expectations, provided no incentive to export to Lima low-value, high-bulk crops. In pastoral farming, only a few haciendas were reorganised along capitalist lines while most remained in an archaic state, farming extensively, and with production increasing only slowly» (Miller 1979, p. 47). It seems, then, that the railroads in Peru did not develop significant linkages with non-exporting sectors, which reduced the impact of the railroad on the Peruvian economy.

As Miller (1979) indicates, in pastoral farming only a few haciendas were truly capitalist. In general, it is possible that other factors (not necessarily related to transportation infrastructure) limited the growth of the economy beyond the traditional export sector. More research needs to be done, but if the Peruvian economy was too underdeveloped and therefore the gains from specialisation were not large enough, the demand for rail transport services (especially, for long routes) was probably not high enough. With a low demand, it is not surprising that only a few railroads were built.

Information about rail and non-rail freight rates may also be relevant to an understanding of the low social savings of railroads of Peru. The cost of non-rail transportation in Peru was high in comparison with other countries in the region. Mule rates were 0.15 dollars/tonne-km in 1914, whereas wagon rates were $<0.1$ dollar/tonne-km in Mexico, Argentina and Uruguay. Only in Brazil was the cost of non-rail transport higher than in Peru. However, in spite of these high pre-rail freight rates, the reduction in freight rates in Peru was not higher than that in other Latin American countries. In fact, around 1914, such reduction of freight rates in Peru was lower (although only slightly) than in Mexico and Brazil ${ }^{49}$.

The reason for this low reduction in freight rates in spite of the high nonrail price of transportation was that rail freight rates in Peru were relatively high by Latin American standards. By 1914, for example, the average rail rate in Peru was 0.03 dollars of 1900/tonne-km, greater than the Brazilian rate, and much higher than in Mexico, Argentina and Uruguay. The high rates of the railroads in Peru certainly generated discontent among the population. Peruvians usually complained that the Central Railways' rates were very high, retarding the development of the economy. In an editorial, the newspaper El Pais indicated that it was notorious that the department of Junin

\footnotetext{
48 These figures were collected by Miller (1976b).

49 With respect to Uruguay and Argentina, however, the reduction of freight rates due to the railroad was not necessarily lower.
} 
(located in the central highlands) alone could supply not only Lima and Callao with potatoes, wheat, and other foodstuff, but also much of the Peruvian coast, but high transport costs did not make it possible ${ }^{50}$. In 1899 , the Financial Times quoted the Peruvian government's position as expressed in an official publication: "The rates of freight charged by the [Peruvian] Corporation, especially on the Central line... are exorbitantly high, so much so that they are actually 16 times higher than those charged on the railway between Veracruz and Mexico. As a result of these high freights we still see in Peru the ridiculous competition of mules, asses and llamas with the railways in the carriage of produce and merchandise... $\nu^{51}$.

Railroad rates in Peru may have been high as a result (at least, partly) of high operating costs. Miller (1976b) indicates that, "on certain grounds the Peruvian Corporation could justify relatively high tariffs on the Central Railway. Both the mountain railways of Peru [the Central Railway and the Southern Railway] faced considerable technical problems that raised their costs, and led them to charge higher tariffs than elsewhere in South America. Both climbed to over $15,000 \mathrm{ft}$. In any circumstances the gradients involved would have increased the cost of locomotive power by raising fuel and maintenance $\operatorname{costs} »^{52}$.

\section{CONCLUSIONS}

One might conclude from the literature that the lack of waterways led to large social savings of railroads. In the United States and Great Britain, for example, canals and rivers provided a low-cost transportation service; whereas in Brazil and Mexico, the lack of waterways implied that shippers and passengers would have had to rely on the costly wagon system if railroads had not been built.

In the case of Peru, however, waterways were not available, and the only substitute to railroads was the costly and inefficient system of mules and llamas. Contemporary sources indicate that transportation in most of the country was conducted on the backs of mules and llamas. This system was slow and expensive. Thus, the construction of railroads from the mid-19 $9^{\text {th }}$ century generated much optimism.

Peru devoted resources to the construction of railroads. However, its railroad length was highly limited. Only a few towns were linked by railroads,

${ }^{50}$ El País, August 31, 1895, cited by Miller (1976b, p. 36).

${ }^{51}$ Financial Times, April 28, 1899, cited by Miller (1976b, p. 41).

52 Miller (1976b, p. 42). Miller reaches this conclusion from an interview with D. Russell, in Arequipa, in November of 1972. Some railroads represented extraordinary engineering accomplishments, especially those that connected the coast and the highlands, passing through the Andes Mountains. The Central Railway, for example, which ran from Callao to La Oroya, was built through the Andes Mountains, reaching an altitude of $4147 \mathrm{~m}$ in Casapalca. 
so most Peruvians had to rely on the traditional system of mules and llamas for their transportation. As a result, the size of the railroad sector was very small. In addition, the evidence indicates that railroads in Peru reduced freight rates. However, rail freight rates in Peru were relatively high, probably as a result of the complex geography of the Peruvian Andes and the consequently high operating costs.

Railroads certainly reduced transport costs, but their direct benefits were not as large as expected. In 1914, for example, social savings of the railroad ranged between 2 per cent and 7 per cent of GDP. The social savings were similar to those in the United States (even though the substitute to railroads in the United States was constituted by canals and navigable rivers), and were much lower than in Mexico, Brazil and Argentina. It seems then that railroads in Peru did not meet the expectations of their $19^{\text {th }}$ century promoters.

This low level of social savings is largely explained by the low level of freight savings. Railroads yielded low freight savings largely because of the small size of the railroad sector. In the early 1910s, for example, the size of the railroad sector (measured as total rail freight revenues as percentage of GDP) was much greater in Mexico, Brazil and Argentina than in Peru. These differences in the size of the railroad sector are not surprising considering the low total length of railroad track of Peru. In spite of the differences in freight rates between railroads and the traditional system of transportation, it seems that the demand for rail transportation was not large enough to promote sufficient investment in railroad construction.

\section{REFERENCES}

BASAdRe, J. (1983): Historia de la República del Perú. Vol. V. Lima: Editorial Universitaria. Bonilla, H. (2005): El Futuro del Pasado. Las Coordenadas de la Configuración de los Andes. Lima: Fondo Editorial del Pedagógico San Marcos, Instituto de Ciencias y Humanidades.

Briceño y Salinas, S. (1921): Itinerario General de la República. Lima.

BRiceño y Salinas, S. (1927): Cuadro General para el Término de Distancia Judicial, Civil y Militar dentro de la República y aun en el extranjero. Lima.

Bulmer-Thomas, V. (2003): The Economic History of Latin America since IndependenceCambridge University Press.

CARON, F. (1983): «France», in P. O’Brien (ed.), Railways and the Economic Development of Western Europe, 1830-1914. New York: St. Martin's Press.

Cisneros, C. (1906): Reseña Económica del Perú. Lima: Imprenta "La Industria".

Cisneros, C. (1911): "Monografía de Lima». Boletín de la Sociedad Geográfica de Lima, Vol. 26 and 27. Lima: Sociedad Geográfica de Lima.

Coatsworth, J. (1979): «Indispensable Railroads in a Backward Economy: The Case of Mexico». The Journal of Economic History 39 (4), pp. 939-960.

Contreras, C. (2004): El aprendizaje del capitalismo. Estudios de historia económica y social del Perú Republicano. Lima: IEP. 
Costa y Laurent, F. (1908): Reseña Histórica de los Ferrocarriles del Perú. Lima: Ministerio de Fomento, Litografía Tip. Carlos Fabbri.

Dávalos y Lissón, P. (1919): La Primera Centuria. Lima: Librería e Imprenta Gil.

Deustua, J. (2009): El embrujo de la plata. La economía social de la minería en el Perú del siglo XIX. Lima: BCRP, IEP.

Edgerton, D. (2006): The Shock of Old: Technology and Global History since 1900. Oxford: Oxford University Press.

Fishlow, A. (1965): American Railroads and the Transformation of the Ante-Bellum Economy. Cambridge: Harvard University Press.

Flores-Galindo, A. (1993): “Arequipa y el Sur Andino", Obras Completas, Vol. I. Lima: Fundación Andina, SUR Casa de Estudios del Socialismo.

Fogel, R. (1962): "A Quantitative Approach to the Study of Railroads in American Economic Growth: A Report of Some Preliminary Findings». The Journal of Economic History 22 (2), pp. 163-197.

Fogel, R. (1964): Railroads and American Economic Growth: Essays in Econometric History. Baltimore: The Johns Hopkins Press.

Fogel, R. (1979): «Notes on the Social Savings Controversy». The Journal of Economic History 39 (1), pp. 1-54.

Fremdling, R. (1977): «Railroads and German Economic Growth: A Leading Sector Analysis with a Comparison to the United States and Great Britain». The Journal of Economic History 37 (3), pp. 583-604.

Fremding, R. (1983): «Germany», in P. O'Brien (ed.), Railways and the Economic Development of Western Europe, 1830-1914. New York: St. Martin's Press.

Gómez-MendozA, A. (1983): «Spain», in P. O’Brien (ed.), Railways and the Economic Development of Western Europe, 1830-1914. New York: St. Martin's Press.

Gootenserg, P. (1993): Imagining Development. Economic Ideas in Peru's "Fictitious Prosperity" of Guano, 1840-1880. Berkeley, Los Angeles, London: University of California Press.

Gunderson, G. (1970): «The Nature of Social Saving». The Economic History Review, New Series 23 (2), pp. 207-219.

Hawke, G. (1970): Railways and Economic Growth in England and Wales, 1840-1870. London: Oxford University Press.

Herranz-Loncán, A. (2011): «The Role of Railways in Export-Led Growth. The Case of Uruguay, 1870-1913». Economic History of Developing Regions 26 (2), pp. 1-32.

Hills, S. (1860): Travels in Peru and Mexico, Vol. I and II. London: Longman, Green, Longman and Roberts.

Jones, C. (1927): «The Commercial Growth of Peru». Economic Geography 3 (1), pp. 23-49.

Laffut, M. (1983): «Belgium», in P. O'Brien (ed.), Railways and the Economic Development of Western Europe, 1830-1914. New York: St. Martin's Press.

McEvoy, C. (2004): La Huella Republicana Liberal en el Perú. Manuel Pardo. Escritos fundamentales. Lima: Fondo Editorial del Congreso del Perú.

Metzer, J. (1974): «Railroad Development and Market Integration: The Case of Tsarist Russia». The Journal of Economic History 34 (3), pp. 529-550.

Miller, R. (1976a): "The Making of the Grace Contract: the Peruvian Government and the British Bondholders, 1885-1890». Journal of Latin American Studies 8 (1), pp. 73-100.

Miller, R. (1976b): «Railways and Economic Development in Central Peru, 1890-1930», in R. Miller, C. Smith, and J. Fisher (eds), Social and Economic Change in Modern Peru, Center for Latin American Studies. Liverpool: University of Liverpool.

MILleR, R. 1979. "British Business in Peru, 1883-1930», PhD Thesis, University of Cambridge. 
Milstead, H. (1928): «Distribution of crops in Peru». Economic Geography 4 (1), pp. 88-106. O'Brien, P. (ed.) (1983): Railways and the Economic Development of Western Europe, 1830-1914. New York: St. Martin's Press.

Pino, J. (1910): "El Estado y la mujer", Revista Universitaria. Lima: Tesis de Bachiller de Ciencias Políticas.

Pinto, M., and, Salinas, A. (2009): Las rutas del café y el trigo. Los ferrocarriles de Chanchamayo y Huancavelica 1886-1932. Seminario de Historia Rural Andina, Lima: Universidad Nacional Mayor de San Marcos.

Quiroz, A. (1993): Domestic and Foreign Finance in Modern Peru, 1850-1950, Financing Visions of Development. Pittsburgh: University of Pittsburgh Press.

Ramírez, M. (2000), "Railroads and the Colombian Economy», Bogota: Banco de la República, mimeo, paper presented at the 2000 Econometric Society World Congress.

Roel, V. (1986): El Perú en el Siglo XIX. Lima: Librería y Distribuidora "El Alba” E.I.R.L.

Seminario, B.; Alva, N., and Ponce, L. (2010): La Economía en el Perú Republicano, Serie Documentos de Trabajo, No. 3. Lima: CEPLAN.

Summerhill, W. (2005): «Big Social Savings in a Small Laggard Economy: Railroads-led Growth in Brazil». Journal of Economic History 65 (1), pp. 72-102.

Tizón y Bueno, R. (1909): Algunos artículos sobre vialidad nacional. Lima: Tipografía Nacional Pedro Berrio.

ToRREJón, L. (2010): Rebeldes Republicanos: La turba urbana de 1912. Lima: Red para el Desarrollo de las Ciencias Sociales.

Tschudi, J. (1847): Travels in Peru During the years 1838-1842 on the Coast, in the Sierra, Across the Cordillera and the Andes, into the Primeval Forests. London: David Bogue.

Vivian, E. (1921): Peru. Physical Features, Natural Resources, Means of Communication, Manufactures and Industrial Development. New York: D. Appleton \& Company.

WASzKIs, H. (1993): Mining in the Americas: Stories and History, Abington. Cambridge: Woodhead Publishing Limited.

ZegarRa, L. F. (2011): «Transport Costs and Economic Growth in a Backward Economy. The Case of Peru, 1820-1920». Journal of Iberian and Latin American Economic History 29 (3), pp. 361-392. 